\title{
Ephemeroptera, Plecoptera and Trichoptera assemblages in litter in a mountain stream of the Atlantic Rainforest from Southeastern Brazil
}

\author{
Vera L. Crisci-Bispo '; Pitágoras C. Bispo ${ }^{1,3} \&$ Claudio G. Froehlich ${ }^{2,3}$ \\ 1 Laboratório de Biologia Aquática, Departamento de Ciências Biológicas, FCLA, Universidade Estadual Paulista. Avenida \\ Dom Antônio 2100, Caixa Postal 65, 19806-900 Assis, São Paulo, Brasil. E-mail: crisci@usp.br; pitagoras@assis.unesp.br \\ 2 Departamento de Biologia, FFCLRP, Universidade de São Paulo. Avenida Bandeirantes 3900, 14040-901 Ribeirão Preto, \\ São Paulo, Brasil. E-mail: cgfroeh@usp.br \\ ${ }^{3}$ CNPq Researcher.
}

\begin{abstract}
The study of Ephemeroptera, Plecoptera and Trichoptera associated with litter in southeastern Brazil streams aimed to answer the following questions: 1) Does richness and composition of EPT fauna differ between riffle and pool mesohabitats despite being associated to the same substratum, litter? 2) Does the similarity of the EPT fauna between both mesohabitats change with time? 3) Does the EPT functional feeding structure differ between both mesohabitats (riffles-pools)? In order to answer these questions, monthly collections, from November 1999 to June 2000, were done in Ribeirão (Stream) Bocaina with a D-net (10 litter patches in riffles and 10 in pools). The EPT fauna at Ribeirão Bocaina was more diversified and more abundant in the litter in riffles than in the litter in pools, although, when richness was standardized for the same number of individuals it became similar in both conditions. EPT fauna was very different between both mesohabitats in terms of faunal composition as well as in terms of function. Probably it was due to differences in water speed, in the time of litter residence and in the concentration of dissolved oxygen between both mesohabitats. KEY WORDS. Aquatic insects; aquatic macroinvertebrates; EPT; lotic environments.
\end{abstract}

RESUMO. Comunidades de Ephemeroptera, Plecoptera e Trichoptera em folhiço de um riacho de montanha da Mata Atlântica do Sudeste do Brasil. A fauna de Ephemeroptera, Plecoptera e Trichoptera associadas ao folhiço em um riacho do sudeste do Brasil foi estudada com o objetivo de responder às seguintes questões: 1) A riqueza e a composição faunística de EPT difere entre os dois mesohabitats (corredeira-remanso) mesmo quando associadas ao mesmo substrato, folhiço? 2) A similaridade da fauna de EPT entre os dois mesohabitas muda temporalmente? 3) A estrutura funcional de EPT difere entre os dois mesohabitats (corredeira-remanso)? Para responder essas questões, coletas mensais, de novembro de 1999 a junho de 2000, foram feitas no Ribeirão Bocaina com rede D (10 acúmulos de folhas em remanso e 10 em corredeira). A fauna de EPT do Ribeirão Bocaina foi mais diversificada e mais abundante no folhiço em corredeira do que no folhiço em remanso, no entanto, quando a riqueza foi padronizada para o mesmo número de indivíduos essa se tornou similar para as duas condições. A fauna de EPT foi bastante diferente entre os dois mesohabitats, tanto em termos da composição faunística quanto em termos funcionais. Isso provavelmente ocorreu devido às diferenças de velocidade da água, no tempo de residência do folhiço e na taxa de oxigênio da água entre os dois mesohabitats.

PALAVRAS-CHAVE. Ambientes lóticos; EPT; insetos aquáticos; macroinvertebrados aquáticos.

The distribution of aquatic organisms in lotic environments is determined by many factors, which operate in different scales, from the most ample scales to the local ones. Considering local scales, mountain streams present a large variability, constituting a mosaic of habitats with different environmental characteristics. This heterogenity in each stretch of the stream is crucial for the distribution patterns of aquatic organisms, as many organisms show preferences for particular characteristics of habitat (Minshall 1984).

In a stream, mesohabitat may be defined as visually distinct unit of habitat with an evident physical uniformity (PARDO \& ARmitage 1997). In mountain streams there is generally the formation of a riffle-pool system. On the one hand, riffle mesohabitats have high water speed and, for this reason, they are an erosive environment, characterized by an irregular water flux and a predominance of rocky substrata. On the other 
hand, the pool mesohabitats have lower water speed, what makes them depositional habitats. Usually they are deeper than riffles, have a more uniform flux and a predominance of organic detritus and fine substrata.

As most benthic organisms present low mobility, local factors have great importance for their distribution. Considering the fact that the organisms are adapted to a specific combination of environmental factors, it is expected that different environment characteristics, represented by riffles and pools, determine the distribution of those organisms in each part of the stream (KoBAYASHI \& KagAYA 2002).

In this work, data from EPT associated with litter were collected in a mountain stream with the aim of answering the following questions: 1) Does richness and composition of EPT fauna differ between both mesohabitats (riffles-pools) even when associated with the same substratum, litter? 2) Does the EPT fauna similarity between both mesohabitats change with time? 3) Does the EPT functional feeding structure differ between both mesohabitats?

\section{MATERIAL AND METHODS}

\section{Study area}

This study was carried out in a stream of the Intervales State Park. The Park is located in the Serra de Paranapiacaba, South of São Paulo State, and includes areas of the municipalities of Ribeirão Grande, Eldorado, Guapiara, Iporanga and Sete Barras. The Park is situated at coordinates $24^{\circ} 12^{\prime}-24^{\circ} 25^{\prime} \mathrm{S}$ and $48^{\circ} 03^{\prime}-48^{\circ} 30^{\prime} \mathrm{W}$. Its area is approximately $380 \mathrm{~km}^{2}$ and it represents one of the last well-preserved areas of the Atlantic Forest. Altitudes vary from 70 to $1000 \mathrm{~m}$.

The highest ridges define the watershed between the Ribeira de Iguape River catchment in the direction of the coast and the Paranapanema River catchment flowing inland. Concerning the hydrological classification, within the Park, the rivers vary from $1^{\text {st }}$ to $5^{\text {th }}$ order. It rains all along the year and this promotes high air humidity.

\section{Collection and identification}

This study was carried out in the Bocaina Stream ( $24^{\circ} 16^{\prime} 13^{\prime \prime}$ S and $\left.48^{\circ} 27^{\prime} 09^{\prime \prime} \mathrm{W}\right)$, which belongs to the Ribeira de Iguape basin. The studied stretch is $2^{\text {nd }}$ order (sensu STRAHLER 1957), with a dense canopy cover, presence of riffles and pools, and plant litter accumulations are common. During collections, the following environmental factors were registered: air and water temperatures $\left({ }^{\circ} \mathrm{C}\right.$, alcohol thermometer), water speed $(\mathrm{m} / \mathrm{s}$, floater method), discharge $\left(\mathrm{m}^{3} / \mathrm{s}\right.$, according to the methodology described in LIND 1979), electric conductivity ( $\mu \mathrm{S} / \mathrm{cm})$, hydrogenionic potential $(\mathrm{pH})$, water turbidity (NTU) and dissolved oxygen $(\mathrm{mg} / \mathrm{l})$, the last four being measured with portable meters. The characterization of the stream is presented in table I.

Aquatic macroinvertebrates were sampled monthly from November 1999 to June 2000 in litter in riffles and in pools. In each collection, 10 litter patches $\left(0,01 \mathrm{~m}^{2}\right.$ each) were sampled in riffles and another 10 in pools with a D-net.
Table I. Environmental characterization of the Bocaina stream (from November 1999 to June 2000, means), Intervales State Park, São Paulo.

\begin{tabular}{lr}
\hline \multicolumn{2}{c}{ Environmental factors } \\
\hline Air temperature $\left({ }^{\circ} \mathrm{C}\right)$ & 16.460 \\
Water temperature $\left({ }^{\circ} \mathrm{C}\right)$ & 18.160 \\
Water speed $(\mathrm{m} / \mathrm{s})$ & 0.325 \\
Discharge $(\mathrm{m} 3 / \mathrm{s})$ & 0.144 \\
Hydrogenionic potential $(\mathrm{pH})$ & 7.910 \\
Electric conductivity $(\mathrm{mS} / \mathrm{cm})$ & 121.500 \\
Dissolved oxygen $(\mathrm{mg} / \mathrm{l})$ & 8.550 \\
Water turbidity $(\mathrm{NTU})$ & 3.720 \\
\hline
\end{tabular}

The Ephemeroptera, Plecoptera and Trichoptera immatures were sorted out and identified to genus. For this, the following keys were used: Domínguez et al. (1992) for Ephemeroptera, Benedetto (1974) and Froehlich (1984) for Plecoptera, and Angrisano (1995) and Wiggins (1998) for Trichoptera. The EPT genera were included in the functional feeding categories proposed by Cummins \& KLUG (1979) using data from the literature (MERRITT \& Cummins 1996, Wiggins 1998, Polegatto \& Froehlich 2003) and observations in the field. The trophic functional categories considered were collectors, scrapers, shredders and predators.

\section{Data analysis}

Richness was evaluated by rarefaction curves (HURLBERT 1971, Simberloff 1972) using a Monte Carlo permutation method. To estimate the number of taxa for $\mathrm{k}$ individuals, $\mathrm{k}$ individuals were randomly withdrawn from the sample and the observed number of taxa was recorded. That procedure was repeated 1000 times. The procedures were carried out using the Ecosim 5 simulation program (Gotelli \& ENTSMINGER 2000).

The logarithmized abundance matrix $[\log (\mathrm{x}+1)]$ was submitted to the Detrended Correspondence Analysis (DCA). DCA was carried out using the PC-ORD 4.0 program (MCCunE \& MEFFord 1999). The logarithmized matrix was also used to calculate a similarity matrix among the samples (Q mode), using the Morisita-Horn Index (HoRN 1966, KREBS 1999). Visualization of that matrix was obtained through an agglomerative cluster analysis (Romesburg 1984). UPGMA was used to obtain the dendrogram (Krebs 1999). The dendrogram distortion was evaluated by the cophenetic correlation index (CCI) (Romesburg 1984). That index was obtained correlating the original similarity matrix with the matrix obtained from the dendrogram; $r \geq 0.8$ is considered a good value (RoHLF 2000). The cluster analysis was carried out using the NTSYS 2.1 program (RohlF 2000).

The indicator taxa analysis employed in this study followed the method described by DuFrêne \& LEGENDRE (1997). This method is known as ISA that stands for Indicator Species Analysis. According to this technique, there are groups, in the data set, which can be indicated by some taxa. These groups are established a priori; in our case, groups were defined as samples 
collected in litter from riffles and in litter from pools. For each taxon, its indicator value is given to each one of the groups. The maximum indicators that are found, for a specific group, are statistically tested through Monte Carlo permutation; in this work 1000 permutations were used. The indicator value is given by the product of the relative abundance of taxon $\mathrm{j}$ in group $\mathrm{k}$ and by the relative frequency of taxon $\mathrm{j}$ in group $\mathrm{k}$. This product is multiplied by 100 , since the result is given in percentage.

\section{RESULTS}

The totals of EPT collected in Ribeirão Bocaina from November 1999 to June 2000, in litter in riffles and litter in pools and its respective functional feeding categories are presented in table II. The richness and the number of individuals were greater in litter from riffles (29 taxa, 2555 individuals) than in litter from pools ( 21 taxa, 811 individuals). Nevertheless, the EPT richness between the litter from riffles and those from pools were similar when richness was standardized through the rarefaction method (Fig. 1), in other words, the richness of EPT fauna did not differ between riffle and pools mesohabitats when the same number of individuals was considered. Richness standardized through rarefaction for 800 individuals had 21.62 EPT taxa (18.15-25.09, 95\% confidence interval) for litter from riffles and 20.96 EPT taxa (20.56-21.34, $95 \%$ confidence interval) for litter in pools.

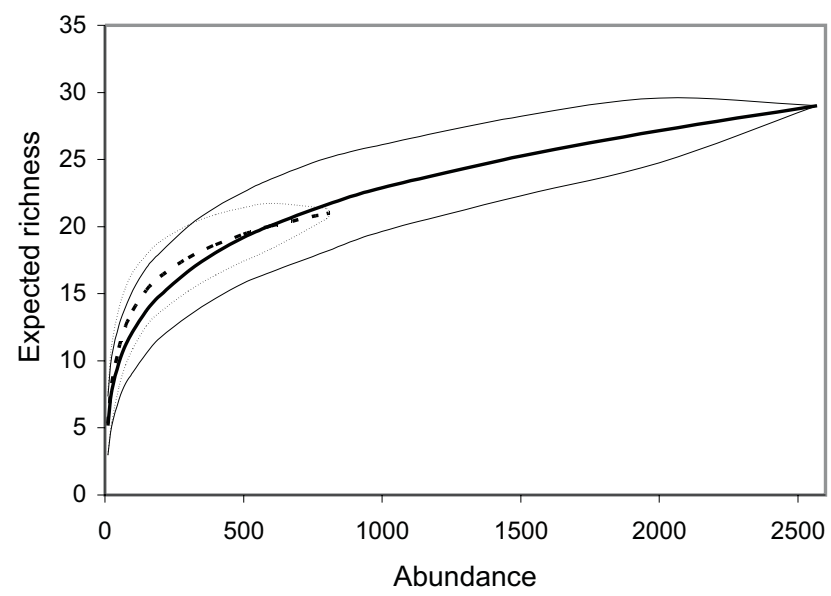

Figure 1. Rarefaction curves of immatures of genera of EPT collected monthly from November 1999 to June 2000 in Bocaina Stream, Intervales State Park, São Paulo. Dashed line, litter in pools; continuous litter in riffles.

The results of this study showed that the composition of EPT fauna differed between riffle and pools mesohabitats. According to the first DCA axis (84.9\% of variance), the dispersion of samples shows that there was a clear separation between the litter fauna of riffles and that of pools (Fig. 2), the

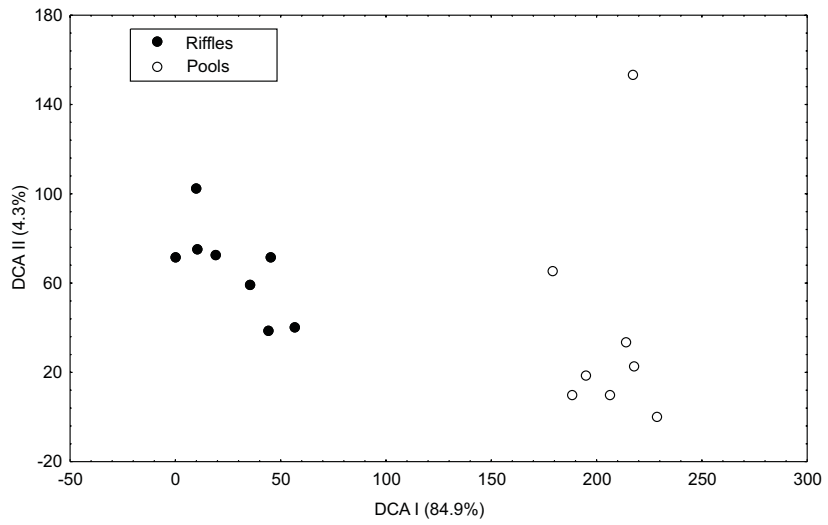

Figure 2. Scores of Detrended Correspondence Analysis (DCA) for EPT assemblages collected monthly in litter in riffles and in pools from November 1999 to June 2000 in Bocaina Stream, Intervales State Park, São Paulo.

samples with greater scores being those collected in pools. The second DCA axis explained only $4.3 \%$ of variance. Considering the first DCA axis, the scores of EPT fauna in litter in both mesohabitats maintained approximately the same similarity during the study period, despite the variation in discharge (Fig. 3). Therefore, the similarity of the EPT fauna between riflles and pools did not change clearly with time.

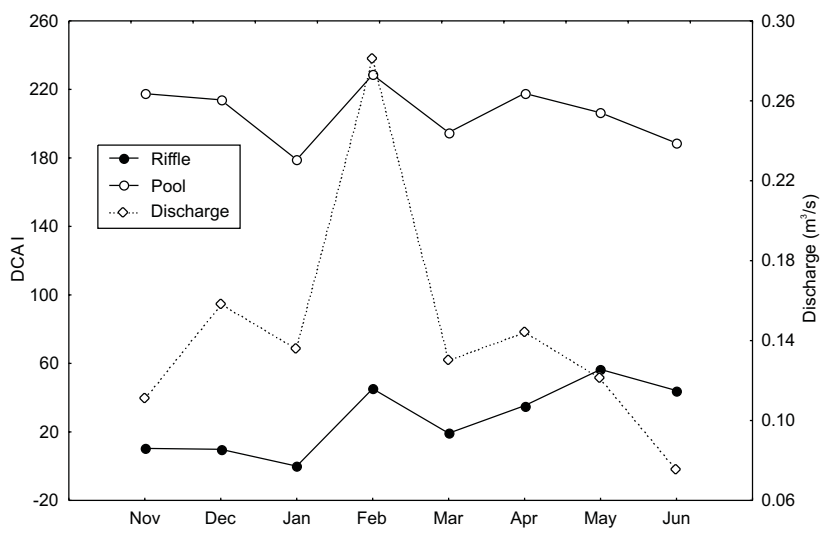

Figure 3. Temporal variation of the discharge $\left(\mathrm{m}^{3} / \mathrm{s}\right)$ and of the scores (according DCA I) of the EPT assemblages collected monthly in litter in riffles and in pools from November 1999 to June 2000 in Bocaina Stream, Intervales State Park, São Paulo.

The dendrogram in figure 4 confirms a clear separation of the fauna of both substrata. Thraulodes, Hylister, Leptonema, Smicridea, Nectopysche, Atopsyche, Anacroneuria and Kempnyia were the taxa that indicated riffles. Massartella, Campylocia, Phylloicus and Triplectides were the indicators of pools (Tab. II). 


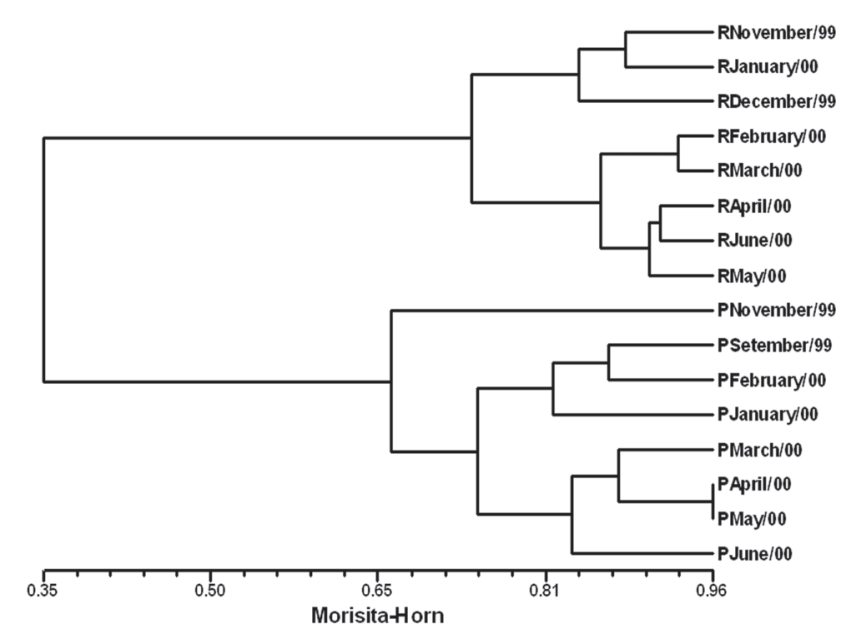

Figure 4. Dendrogram obtained by UPGMA representing the similarity among EPT fauna (Morisita-Horn) collected monthly in litter in riffles (R) and in pools (P) from November 1999 to June 2000 in Bocaina Stream, Intervales State Park, São Paulo. CCl (0.929).

The proportion of each functional feeding category is presented in figure 5. For taxa belonging to more than one category, only the main feeding behaviour was considered. In this study, the EPT functional feeding structure differed between both mesohabitats (riffles-pools). Shredders were dominant in the litter substratum of riffles $(38.19 \%)$, followed by predators $(23.12 \%)$, scrapers (19.90\%) and collectors (18.77\%). In the litter substratum of pools, shredders $(44.51 \%)$ were also the dominant category, followed by scrapers $(40.57 \%)$ and, with a lower percentage, predators (9.37\%) and collectors (5.55\%).

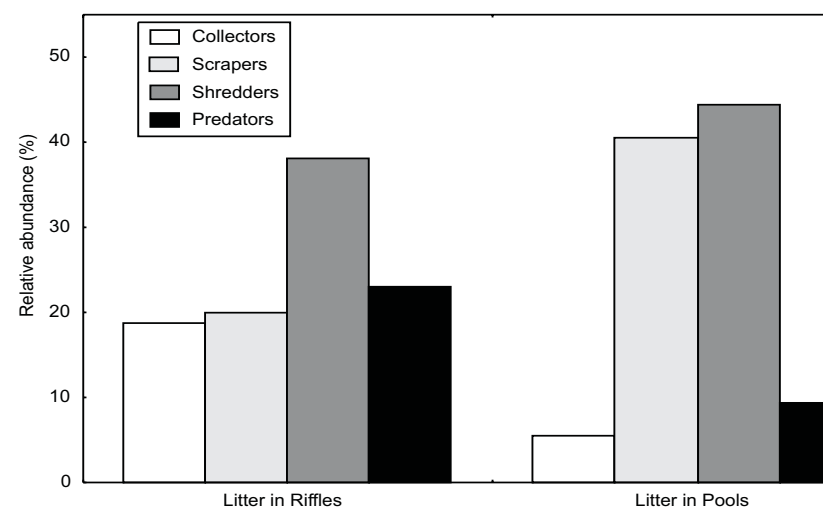

Figure 5. Relative abundance (\%) of the functional feeding categories of EPT collected monthly in litter in riffles and in pools from November 1999 to June 2000 in Bocaina Stream, Intervales State Park, São Paulo.

\section{DISCUSSION}

A common pattern in comparative studies among mesohabitats in streams is the greater abundance and richness in riffle mesohabitats in relation to those of pools (UIEDA \& GAJARDO 1996, BAPTISTA et al. 2001, Buss et al. 2004). In the present study, which only considered EPT in litter, the obtained results corroborated the mentioned works. Neverthless, it is necessary to consider that the greater the number of collected individuals, the greater the number of registered taxa (GotelLi \& Graves 1996); this fact may have introduced a bias, since different numbers of individuals were sampled in both mesohabitats. Here, when EPT richness, considering the same substratum litter, was standardized, it became similar between both mesohabitats. In general, works that compare richness between riffles and pools do not make standardization for the same number of collected individuals, so, it was not possible to evaluate whether the results found in the present work are a general pattern or only a characteristic of the studied fauna.

Riffles and pools are two of the most conspicuous mesohabitats in mountain streams. One of the most important factors that differentiate these two habitats is water speed and this may be a limiting factor for colonization of many aquatic macroinvertebrates. In order to colonize leaves in riffles, the macroinvertebrates need adaptations that enable them to remain adhered to the substratum in conditions of strong flow (Kobayashi \& Kagaya 2002). Hoover et al. (2006) verified a higher rate of decomposition of litter in pools and suggested that litter in riffles may be accessible only for a limited group of detritivorous macroinvertebrates, a situation that could lead to a decrease in the rates of biological fragmentation in riffles. The smaller oxygenation rates in pools, however, may inhibit the colonization by taxa with high oxygen requirements (Kobayashi \& Kagaya 2002). Besides these, another important factor is that litter, in riffles and in pools, is submitted to different hydraulic conditions, which may cause it to present different characteristics (KobaYASHI \& Kagaia 2002). Therefore, factors as speed, oxygen supply and the litter characteristics may arise as possible explanatory factors for the different EPT assemblages registered in the two different mesohabitats considered in this work.

An important observation during the present study was that the taxa indicators of litter in riffles were taxa usually associated with rocky substratum. Therefore, many EPT, indicators of litter in riffles must have used the litter only as substratum, redistributing themselves among the rocks and leaves. Nectopsyche, a small shredder that hold itself on to firm substrata, was an exception to that rule and it was the only shredder which indicated regions of riffles. On the other hand, taxa associated with litter in pools were scrapers or shredders that are characteristics of the accumulation of plant debris.

The functional delimitation between riffle and of pool mesohabitats may change seasonally as an answer to the varia- 
Table II. Numbers of immatures and functional feeding categories of genera of Ephemeroptera, Plecoptera and Trichoptera collected monthly in litter in riffles (R) and in pools (P) from November 1999 to June 2000 in Bocaina Stream, Intervales State Park, São Paulo. Functional feeding categories (FFC): (C) collectors, (Pr) predators, (Sc) scrapers, (Sh) shredders; (IV) indicator value; $p$ to 1000 permutations.

\begin{tabular}{|c|c|c|c|c|c|c|}
\hline Genera & Litter in Riffles & Litter in Pools & FFC & IV (\%) & $\mathrm{P}$ & Indicator of the Mesohabitat \\
\hline Leptohyphes Eaton, 1882 & 53 & 2 & C Sc & 85.2 & 0.003 & $\mathrm{R}$ \\
\hline Gr. Traverhyphes Molineri, 2001 & 2 & & $\mathrm{C}$ & 25.0 & 0.460 & $\mathrm{R}$ \\
\hline Thraulodes Ulmer, 1920 & 172 & 2 & Sc C & 98.9 & 0.001 & $\mathrm{R}$ \\
\hline Hylister Domínguez \& Flowers, 1989 & 178 & 1 & $\mathrm{C}$ & 87.0 & 0.001 & $\mathrm{R}$ \\
\hline Hagenulopsis Ulmer, 1919 & 5 & & $\mathrm{C}$ & 37.5 & 0.180 & $\mathrm{R}$ \\
\hline Farrodes Peters, 1971 & 1 & 10 & Sc C & 45.5 & 0.185 & $P$ \\
\hline Massartella Lestage, 1930 & 7 & 245 & Sc C & 97.2 & 0.001 & $P$ \\
\hline Baetodes Needham \& Murphy, 1924 & 5 & & Sc & 50.0 & 0.069 & $\mathrm{R}$ \\
\hline Cloeodes Traver, 1938 & 3 & & $\mathrm{C}$ & 37.5 & 0.180 & $\mathrm{R}$ \\
\hline Other Baetidae & 9 & 14 & $\mathrm{C}$ & 22.8 & 0.839 & $P$ \\
\hline Caenis Stephens, 1935 & & 6 & C & 50.0 & 0.067 & $P$ \\
\hline Campylocia Needham \& Murphy, 1924 & 1 & 41 & Sh & 85.4 & 0.004 & $P$ \\
\hline Anacroneuria Klapálek, 1909 & 507 & 22 & $\operatorname{Pr}$ & 95.8 & 0.001 & $\mathrm{R}$ \\
\hline Kempnyia Klapálek, 1914 & 57 & 16 & $\operatorname{Pr}$ & 78.1 & 0.014 & $\mathrm{R}$ \\
\hline Macrogynoplax Enderlein, 1909 & 12 & 38 & $\operatorname{Pr}$ & 66.5 & 0.097 & $P$ \\
\hline Tupiperla Froehlich, 1969 & & 8 & C & 25.0 & 0.459 & $P$ \\
\hline Gripopteryx Pictet, 1841 & 1 & & C Sc & 12.5 & 1.000 & $\mathrm{R}$ \\
\hline Paragripopteryx Enderlein, 1909 & 7 & & C Sh & 50.0 & 0.072 & $\mathrm{R}$ \\
\hline Leptonema Guérin, 1843 & 32 & 1 & $\mathrm{CPr}$ & 97.0 & 0.001 & $\mathrm{R}$ \\
\hline Smicridea McLachlan, 1871 & 167 & 3 & C & 98.2 & 0.001 & $\mathrm{R}$ \\
\hline Blepharopus Kolenati, 1859 & 6 & & C & 12.5 & 1.000 & $\mathrm{R}$ \\
\hline Phylloicus Müller, 1880 & 34 & 90 & Sh & 72.6 & 0.046 & $P$ \\
\hline Nectopsyche Müller, 1879 & 938 & 20 & Sh & 85.7 & 0.038 & $\mathrm{R}$ \\
\hline Triplectides Kolenati, 1859 & 8 & 207 & Sh & 96.3 & 0.001 & $P$ \\
\hline Helicopsyche Siebold, 1856 & 326 & 72 & Sc & 71.7 & 0.078 & $\mathrm{R}$ \\
\hline Chimarra Stephens, 1829 & 2 & & C & 25.0 & 0.467 & $\mathrm{R}$ \\
\hline Polycentropus Curtis, 1835 & 1 & 9 & $\mathrm{CPr}$ & 45.0 & 0.177 & $P$ \\
\hline Polyplectropus Ulmer, 1905 & 1 & 1 & $\mathrm{C}$ & 6.2 & 1.000 & $\mathrm{R}$ \\
\hline Atopsyche Banks, 1905 & 18 & & $\operatorname{Pr}$ & 75.0 & 0.006 & $\mathrm{R}$ \\
\hline Grumicha Müller, 1879 & 1 & & $\mathrm{C}$ & 12.5 & 1.000 & $\mathrm{R}$ \\
\hline Barypenthus Burmeister, 1839 & & 3 & $\operatorname{Pr}$ & 25.0 & 0.456 & $P$ \\
\hline Hydroptilidae & 1 & & $?$ & 12.5 & 1.000 & $\mathrm{R}$ \\
\hline Total & 2555 & 811 & & & & \\
\hline
\end{tabular}

tion in flow. At periods of less flow, due to the water level, pools could be more isolated. On the other hand, in periods of higher flow, connectivity between both mesohabitats could increase. In that sense, it could be expected that temporal variation in flow could lead to an increase in similarity between the EPT fauna of both mesohabitats in periods of higher flow. The present work did not confirm that expectation, since, along the period of study, the EPT fauna in the two mesohabitats maintained approximately the same similarity, considering the first axis of DCA, in spite of variation in discharge.

Apart from the composition, the EPT fauna in litter in both mesohabitats also varied from the functional point of view. Shredders and scrapers represented $85 \%$ of the fauna in litter in pools. In regions of riffles, however, these two functional categories represented less than $60 \%$ of the fauna and many individuals were represented by Nectopsyche, a shredder. In litter in 
riffles, the functional categories had an evener distribution, probably because it is a more heterogeneous environment. In litter in pools, predators and collectors presented very low percentages, an indication that the main taxa use litter not only as a substratum but also as an food resource, fragmenting the leaves or scraping the periphyton of conditioned leaf tissues.

The litter accumulated in riffle mesohabitats may be considered transitory, characterizing itself by high mobility and a short time of residence whereas the litter of pools is characterized by a longer time of residence. In that sense, litter in pools regions may allow greater conditioning by microorganisms. So, it is expected that organisms which employ litter, like the shredders and some scrapers of leaves, would prefer the pools while in riffles many organisms use litter only as a substratum. Our results confirm that expectation.

Mesohabitats of riffles and pools constitute discrete habitats with different local environmental conditions; therefore, it is expected each to have a particular faunal and functional structure of aquatic macroinvertebrates (Pardo \& Armitage 1997, Buss et al. 2004). The data of this work confirm that expectation since different EPT assemblages associated to litter occurred in different mesohabitats. In that sense, as the most of the anthropic impacts leads to a homogenization of habitats, the maintenance of structural quality of lotic environments at each scale is fundamental to the maintenance of diversity in those ecosystems.

\section{ACKNOWLEGMENTS}

To Museum of Zoology of the University of São Paulo (USP) and to the administration of the Intervales State Park for the logistic support. VLCB thanks FFCLRP and CAPES for a grant for the development of this study. PCB thanks FAPESP (proc. 98/11074-3, 02/07216-4; 04/09711-8) and CNPq (proc. 473246/ 2004-0) for their support. PCB (proc. 301578/2004-4) and CGF (proc. 304554/2003-0) have productivity grants from CNPq. We also thank the field guide João da Cruz and the driver Márcio Zanetti for their help in field work. Field work was supported by BIOTA/FAPESP, (proc. 98/05073-4) - The Biodiversity Virtual Institute Program (www.biota.org.br).

\section{REFERENCES}

Angrisano, E.B. 1995. Insecta Trichoptera, p. 1199-1224. In: E.C. Lopretto \& G. Tell (Eds). Ecosistemas de aguas continentales. Metodologías para su estudio. La Plata, Ediciones Sur, vol. III, XVIII+504p.

Baptista, D.F.; L.F. Dorvillé; D.F Buss \& J.L. Nessimian. 2001. Spatial and temporal organization of aquatic insect assemblages in the longitudinal gradient of a tropical river. Brazilian Journal of Biology 61 (2): 295-304.

Benedetto, L. 1974. Clave para la determinación de los plecopteros sudamericanos. Studies on Neotropical Fauna and Environment 9: 141-170.

Buss, D.F.; D.F Baptista; J.L. Nessimian \& M. Egler. 2004. Substrate specificity, environmental degradation and disturbance structuring macroinvertebrate assemblages in neotropical streams. Hydrobiologia 518: 179-188.

Cummins, K.W. \& M.J. Klug. 1979. Feeding ecology of stream invertebrates. Annual Review of Ecology and Systematics 10: $147-172$.

Dominguez, E.; M.D. Hubbard \& W.L Peters. 1992. Clave para ninfas y adultos de las familias y géneros de Ephemeroptera (Insecta) sudamericanos. Biología Acuática 16: 1-32.

DufrêNE, M. \& P. LEgENDRE. 1997. Species assemblages and indicator species: the need for a flexible asymmetrical approach. Ecological Monographs 67: 345-366.

Froenlich, C.G. 1984. Brazilian Plecoptera 4. Nymphs of perlid genera from southeastern Brazil. Annales de Limnologie 20 (1-2): 43-48.

Gotelli, N.J. \& G.L. Entsminger. 2000. EcoSim: null models software for ecology. Version 5.0, Acquired Intelligence Inc. and Kesey-Bear. Available in the World Wide Web at: http:/ /homepages.together.net/ gentsmin/ecosim.htm [Acessed in 02.II.2002]

Gotelli, N.J. \& G.R. Graves. 1996. Null models in ecology. Washington, Smithsonian Institution Press, XVI+368p.

Hoover, T.M.; J.S. Richardson \& N. Yonemitsu. 2006. Flowsubstrate interactions create and mediate leaf litter resource patches in streams. Freshwater Biology 51: 435-447.

Horn, H.S. 1966. Measurement of "overlap" in comparative ecological studies. The American Naturalist 100 (914): 419-424.

HurlberT, S.H. 1971. The nonconcept of species diversity: a critique and alternative parameters. Ecology 52: 577-585.

Kobayashi, S. \& T. Kagaya. 2002. Differences in litter characteristics and assemblages between litter patches in pools and riffles in a headwater stream. Limnology 3: 37-42.

Krebs, C.J. 1999. Ecological methodology. New York, Harper $\&$ Row, XII+620p.

LIND, O.T. 1979. Handbook of Common Methods in Limnology. London, The C.V. Mosby Company, XI+199p.

McCune, B. \& M.J. Mefford. 1999. PC-ORD. Multivariate analysis of ecological data. Gleneden Beach, Version 4.0, MjM Software Design.

Merritt, R.W. \& K.W. Cummins. 1996. An introduction to the aquatic insects of North America. Dubuque, Kendall, Hunt Publishing, $3^{\text {rd }}$ ed., XIII+862p.

Minshall, G.W. 1984. Aquatic Insect-Substratum Relationships, p. 358-400. In: V.H. Resh \& D.M. Rosenberg (Eds). The ecology of aquatic insects. New York, Praeger Publishers, XI+625p.

Pardo, I. \& P.D. Armitage. 1997. Species assemblages as descriptors of mesohabitats. Hydrobiologia 344: 111-128.

Polegatto, C.M. \& C.G. Froenulch. 1993. Feeding strategies in Atalophlebiinae (Ephemeroptera: Leptophlebiidae), with considerations on scraping and filtering, p. 55-61. In: E. GAINo (Ed.). Research update on Ephemeroptera and Plecoptera. Perugia, University of Perugia, 488p.

Rohlf, F.J. 2000. NTSYS 2.1: Numerical Taxonomic and

Revista Brasileira de Zoologia 24 (3): 545-551, setembro 2007 
Multivariate Analysis System. New York, Exeter Software. Romesburg, H.C. 1984. Cluster analysis for researchers. Malabar, Robert E. Krieger Publishing, XV+334p.

Simberloff, D. 1972. Properties of the rarefaction diversity measurement. The American Naturalist 106: 414-418.

STRAHLER, H.N. 1957. Quantitative analysis of watershed geomorphology. American Geophysics Union Transactions 33:
913-920.

UIEDA, V.S. \& I.C.S.M. GAJARDO. 1996. Macroinvertebrados perifíticos encontrados em poções e corredeiras de um riacho. Naturalia 21: 31-47.

Wiggins, G.B. 1998. Larvae of the North America Caddisfly Genera (Trichoptera). Toronto, University of Toronto Press, $2^{\text {nd }}$ ed., IX $+457 p$.

Received in 16.II.2007; accepted in 01.VII.2007. 